\title{
Comparative effectiveness of anti-viral drugs with dual activity for treating hepatitis B and HIV co-infected patients: a network meta-analysis
}

Cho Naing ${ }^{1,2^{*}}$ (D) Yong Poovorawan ${ }^{3}$ and Kew Siang Tong ${ }^{1}$

\begin{abstract}
Background: There are randomized trials assessing a variety of antiviral drugs for hepatitis B virus (HBV), but the relative effectiveness of these drugs in the treatment of patients co-infected with human immunodeficiency virus (HIV) remains unclear. The objectives of the current study were to estimate and rank the relative effectiveness of antiviral drugs for treating HBV and HIV co-infected patients.

Methods: Randomized trials, assessing the efficacy of antiviral drugs for HBV and HIV co-infected patients were searched in health-related databases. The methodological quality of the included trials was evaluated using the Cochrane risk of bias tool. Main outcome in this meta-analysis study was the success of treatment by antivirals as determined by virologic response. We performed pairwise and network meta-analysis of these trials and assessed the quality of evidence using the GRADE approach.

Results: Seven randomized trials (329 participants) were included in this network meta-analysis study. A network geometry was formed with six treatment options including four antiviral drugs, adefovir (ADV), emtricitabine (FTC), lamivudine (LMV) and tenofovir disoproxil fumarate (TDF), combination treatment of TDF plus LMV, and placebo. The weighted percentage contributions of each comparison distributed fairly equally in the entire network of evidence. An assumption of consistency required for network meta-analysis was not violated (the global Wald test for inconsistency: $\left.\mathrm{Chi}^{2}(4)=3.63, p=0.46\right)$. The results of estimates showed no differences between the treatment regimens in terms of viral response for treating HBV and HIV co-infected patients, which spanned both benefit and harm (e.g. LMV vs TDF plus LMV: OR: 0.37, 95\%Cl: 0.06-2.41). Overall, the certainty of evidence was very low in all comparisons (e.g. LMV vs TDF plus LMV: 218 fewer per 1000,121 more to 602 fewer, very low certainty). Therefore, we remained uncertain to the true ranking of the antiviral treatments in HBV/ HIV co-infected patients.

Conclusions: The findings suggest that the evidence is insufficient to provide guidance to the relative effectiveness of currently available antiviral drugs with dual activity in treating co-infection of HBV/HIV. Well-designed, large clinical trials in this field to address other important outcomes from different epidemiological settings are recommended.
\end{abstract}

Keywords: Hepatitis B, HIV, Antiviral, Network meta-analysis

\footnotetext{
* Correspondence: cho3699@gmail.com

${ }^{1}$ International Medical University, Kuala Lumpur, Malaysia

2Division of Tropical Heath and Medicine, James Cook University, Townsville,

QLD, Australia

Full list of author information is available at the end of the article
}

(c) The Author(s). 2018 Open Access This article is distributed under the terms of the Creative Commons Attribution 4.0 International License (http://creativecommons.org/licenses/by/4.0/), which permits unrestricted use, distribution, and reproduction in any medium, provided you give appropriate credit to the original author(s) and the source, provide a link to the Creative Commons license, and indicate if changes were made. The Creative Commons Public Domain Dedication waiver (http://creativecommons.org/publicdomain/zero/1.0/) applies to the data made available in this article, unless otherwise stated. 


\section{Background}

Human immunodeficiency virus (HIV) is an RNA virus and hepatitis $B$ virus (HBV) is a partially double stranded DNA virus, both of which share common modes of transmission. Studies have reported that co-infection with HBV and HIV-1 is common [1-3]. Among the 40 million persons infected with HIV worldwide, an estimated 2-4 million are co-infected with HBV [4], albeit with variation in age-specific prevalence, geographic distribution and the predominant routes of transmission $[4,5]$. Hence, the treatment of chronic HBV in HIV-infected individuals with dual antiretroviral therapy (ART) requires careful consideration.

In co-infected patients, HIV accelerates the progression of HBV-related liver disease. It has been reported that HIV infection has negative impact on the natural history of $\mathrm{HBV}$ infection leading to increased rates of persistent infection, higher HBV DNA levels, lower rates of hepatitis Be antigen loss, increased cirrhosis and liver-related mortality, and increased risk of hepatocellular carcinoma (HCC) at lower CD4+ T cell counts [6]. The aim of treating HBV infection is to prevent patients from progressing to the chronic stage $[7,8]$.

Thus far, emtricitabine (FTC), lamivudine (LMV), tenofovir disoproxil fumarate (TDF) and tenofovir alafenamide (TAF) have demonstrated dual activity for HBV and HIV [9]. However, these drugs vary in therapeutic activity and toxicity. There are randomized trials (RCTs) assessing a variety of antiviral drugs for $\mathrm{HBV}$, but their relative effectiveness in the treatment of patients co-infected with HBV and HIV remains unclear. A network meta-analysis permits inferences into the comparative effectiveness of interventions from direct comparisons (i.e., treatments are directly compared within an RCT) and indirect comparisons (i.e., treatments are compared between RCTs by combining results against a common comparator treatment) and it also allows ranking of these different treatments $[10,11]$. Overall, the objectives of the current study were to estimate and rank the relative effectiveness of antiviral drugs for treating HBV and HIV co-infected patients.

\section{Methods}

The current study was performed in accordance with the preferred reporting items for network meta-analyses (PRISMA-NMA) [12]. A protocol of this study is available in PROSPERO (CRD42016035539).

\section{Search}

Relevant RCTs were searched in the health-related databases of Ovid MEDLINE, Ovid Embase, The Cochrane Library, and Google Scholar. The search strategies for the Ovid MEDLINE are given in Additional file 1. Our search was restricted to publications in the English language up to February 2018. To identify ongoing or completed trials, we also searched in ClinicalTrials.gov (http:// www.clinicaltrials.gov/), WHO International Clinical Trials Registry Platform (http://apps.who.int/trialsearch/Default.aspx) and EU Clinical Trials Register (https://www.clinicaltrialsregister.eu/). We did not search for the adverse effects of antiviral drug interventions separately and only used data contained in the publications identified for the present study.

\section{Study selection}

Individual studies were selected based on the PICOS format [13]:

\section{Study Population (P)}

Patients co-infected with $\mathrm{HBV}$ and HIV, regardless of gender, age, the severity of infections and HBV genotype were included.

\section{Interventions (I)}

Antiviral drugs (monotherapy or combination treatment) for the treatment of $\mathrm{HBV}$ infection were considered.

\section{Comparisons (C)}

Data from an antiviral drug versus an alternative antiviral drug, combination treatment, or placebo were included.

\section{Study Outcomes (O)}

Treatment success (virologic response) was defined as achieving undetectable levels of HBV DNA in patients at the end of 1 year (36-52 weeks). This represents the suppression of HBV DNA levels as stated in the primary studies on the scheduled follow-up, regardless of their $\mathrm{HBeAg}$ status. Adverse events/serious adverse events were as stated in the included studies. For example, hepatic failure after the commencement of therapy was defined as an increase in ALT to $>3-5 x$ the upper limit of normal from a baseline value below this level $[14,15]$.

\section{Study design (S)}

RCT.

Studies which did not meet the inclusion criteria were excluded.

\section{Data extraction}

Two review authors independently screened the titles and abstracts of citations from the electronic database search and retrieved full-text of all potentially relevant articles. When studies had duplicate publications, we extracted the maximum amount of data from the available publications. The two review authors then independently checked the full-text articles for eligibility based on the inclusion criteria. The two reviewers extracted data from the included studies using a piloted data extraction sheet. Data collected were authors, country, publication year, participant's characteristics, details of intervention 
and controls regimen (dosage, route of administration, frequency and duration), outcomes, method of outcome measurements, follow-up time points of the outcome and adverse events. Any discrepancy between the two investigators was resolved by discussion and consensus.

\section{Methodological quality assessment}

The methodological quality of the included trials was evaluated, using the Cochrane risk of bias tool [16]. We checked three domains for the risk of bias assessment such as adequate sequence generation, allocation concealment, blinding of participants and outcome assessors for each trial for the virologic response. As there was only one outcome in the current review, the risk of bias assessments at the outcome level was applied to the whole study. We used these ratings to further Grading of Recommendations Assessment, Development, and Evaluation (GRADE) assessment for risk of bias category accordingly [17].

\section{Data synthesis}

Main outcome in this review was success of treatment by HBV antiviral treatment as determined by virologic response. The intention-to-treat (ITT) analysis was used for efficacy assessments.

\section{Pairwise comparison}

If the studies included had been reported in similar ways (i.e. the comparators, the outcomes reported and follow-up time point), then direct pairwise meta-analyses of head-to-head comparisons were performed using standard frequentist approaches. We used odds ratio (OR) along with 95\%confidence interval (CI) for the dichotomous variable as a measure of the strength of association between the treatment used and efficacy/adverse events. We pooled ORs with a DerSimonian-Laird random-effects model, as the heterogeneity was high $\left(I^{2}>50 \%\right)$ [13]. Initially, we planned to perform a sensitivity analysis to investigate the potential impact of studies at high risk of bias in the pooled studies. We also planned to do stratified analysis by prior LMV naive or LMV experienced. However, the number of studies identified was too small to carry out these analyses. Publication bias was not assessed with the contoured-enhanced funnel plot because the number of included studies was fewer than the recommended 10 included studies [13]. We assumed the risk of

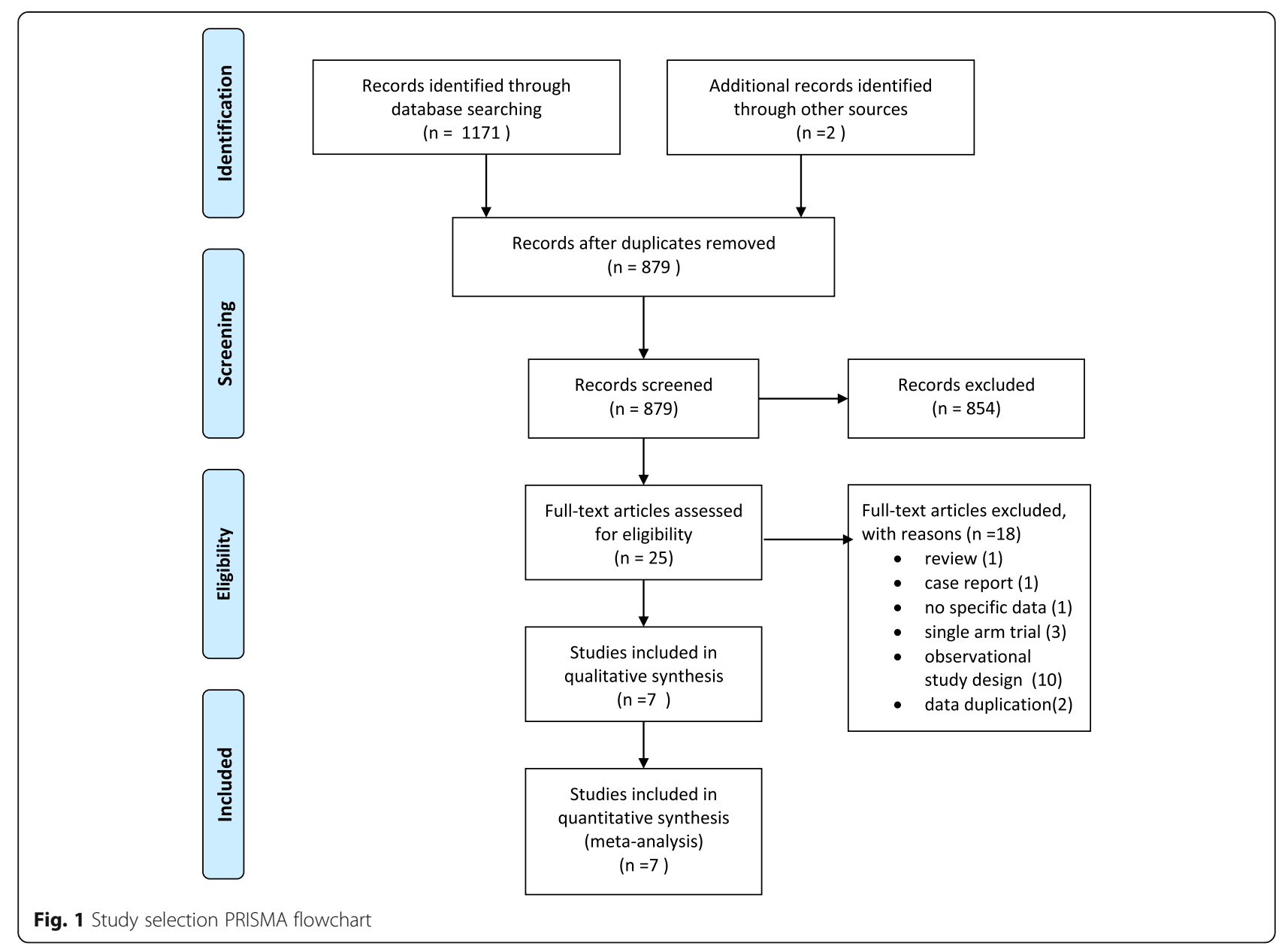


publication bias may be higher as the estimates were based on small RCTs [18].

\section{Network meta-analyses}

We performed network meta-analyses within a frequentist framework using random-effects models $[10,19,20]$. The approach incorporated both direct and indirect information through the use of a common comparator to obtain estimates of the relative interventional effects on multiple intervention comparisons. We established network connections. The percentage contribution of each estimate to the entire network was calculated. The results were presented as contribution plots in which the weighted squares indicated the percentage contribution of each comparison [21].
We investigated network inconsistency with the use of the global Wald test for inconsistency [22]. The network meta-analysis results were reported for 'mixed treatment contrasts', including both direct and indirect evidence from across the entire network [21, 22]. For a ranking of the effectiveness and the uncertainty, probability values were summarised and reported as 'Surface Under the Cumulative Ranking Curve' (SUCRA), as described elsewhere $[11,19]$. SUCRA $=1$ or 0 , if an antiviral drug intervention ranked first or last, respectively. Statistical significance was set at $p$ value $\leq 0.05$.

\section{Assessing the quality of evidence}

We assessed the quality of evidence derived from the pairwise and network meta- analysis, following the

Table 1 Characteristics of the studies included in the network meta-analysis

\begin{tabular}{|c|c|c|c|c|c|c|c|c|c|c|}
\hline $\begin{array}{l}\text { Study } \\
\text { [Reference No] }\end{array}$ & Country & $\begin{array}{l}\mathrm{RCT} \\
\text { design }\end{array}$ & $\begin{array}{l}\text { Total } \\
\text { samples }\end{array}$ & $\begin{array}{l}\text { Age in year } \\
\text { (SD or range) }\end{array}$ & Males & Comparators & $\begin{array}{l}\text { Time point } \\
\text { in week }\end{array}$ & $\begin{array}{l}\text { Diagnosis } \\
\text { of HBV }\end{array}$ & $\begin{array}{l}\text { Main mode } \\
\text { of transmission }\end{array}$ & Remarks \\
\hline $\begin{array}{l}\text { Dore, } 1999 \\
\text { [14] }\end{array}$ & $\begin{array}{l}\text { Canada, } \\
\text { Australia, } \\
\text { Europe, \& } \\
\text { South Africa } \\
\text { (CAESAR) }\end{array}$ & $\begin{array}{l}2 \text { arms; } \\
\text { ITा }\end{array}$ & 122 & $\begin{array}{l}37^{\mathrm{a}} \\
\text { (range: 22-70) }\end{array}$ & $96 \%$ & $\begin{array}{l}\text { LMV } \\
\text { (150 mg } \\
\text { twice/D) vs } \\
\text { placebo }\end{array}$ & $\begin{array}{l}4,8,12 \\
20,28,36 \\
44,52\end{array}$ & $\begin{array}{l}\text { Amplicor } \\
\text { PCR } \\
\text { (Roche, NJ) }\end{array}$ & & $\begin{array}{l}68 \% \mathrm{ART} \\
\text { received }\end{array}$ \\
\hline $\begin{array}{l}\text { Dore, } 2004 \\
\text { [25] }\end{array}$ & $\begin{array}{l}\text { Western EU, } \\
\text { North } \\
\text { America, } \\
\text { Australia }\end{array}$ & $\begin{array}{l}2 \text { arms; } \\
\text { as treated }\end{array}$ & $\begin{array}{l}\text { Gr 1: } 12 \\
\text { Gr2:11 }\end{array}$ & $\begin{array}{l}\text { Gr 1: } 40^{a} \\
\text { Gr2:42 }\end{array}$ & $100 \%^{\mathrm{a}}$ & $\begin{array}{l}\text { Gr1: TDF } \\
\text { (300 mg/D) } \\
\text { vs placebo. } \\
\text { Gr } 2: T D F \\
\text { (300 mg/D) } \\
\text { vs TDF + LMV } \\
\text { (150 mg } \\
\text { twice/D). }\end{array}$ & $12,24,48$ & $\begin{array}{l}\text { HBV DNA } \\
\text { (Roche } \\
\text { Amplicor), }\end{array}$ & & $\begin{array}{l}\text { A sub-study } \\
\text { of } 908 \text { ART } \\
\text { exp. (Gr1) \& } \\
903 \text { naive } \\
\text { (Gr2); ART } \\
\text { naïve group } \\
\& \text { ART } \\
\text { experienced } \\
\text { group }\end{array}$ \\
\hline $\begin{array}{l}\text { Peters, } 2006 \\
{[26]}\end{array}$ & USA & $\begin{array}{l}2 \text { arms; } \\
\text { ITा }\end{array}$ & 52 & $47^{a}$ & $24 \%$ & ADV vs TDF & $12,24,36,48$ & $\begin{array}{l}\text { Roche } \\
\text { Amplicor } \\
\text { CobasPCR }\end{array}$ & IVDU:13.5\% & $\begin{array}{l}\text { stop early } \\
\text { after interim } \\
\text { results }\end{array}$ \\
\hline $\begin{array}{l}\text { Mathews, } \\
2008 \text { [27] }\end{array}$ & $\begin{array}{l}3 \text { countries; } \\
\text { Netherlands, } \\
\text { Australia \& } \\
\text { Thailand (NAT) }\end{array}$ & $\begin{array}{l}3 \text { arms; } \\
\text { ITा }\end{array}$ & 36 & 35.5 (SD: \pm 8.4$)$ & $64 \%$ & $\begin{array}{l}\text { LMV } \\
(150 \mathrm{mg} \\
\text { twice/D); } \\
\text { TDF } \\
\text { (300 mg/D) }\end{array}$ & $12,24,48$ & $\begin{array}{l}\text { Versant HBV } \\
\text { DNA } 3.0 \\
\text { bDNA assay } \\
\text { (Bayer } \\
\text { HealthCare, NY); } \\
\text { COBAS } \\
\text { TaqMan } \\
\text { HBV Test } \\
\text { (Roche } \\
\text { Diagnostics NJ). }\end{array}$ & Hetero (78\%) & $\begin{array}{l}\text { ART naiìve; } \\
\text { EFV } \\
\text { ( } 600 \text { mg/D) } \\
\text { to all } 3 \text { groups; } \\
7 \text { (19\%) } \\
\text { with AIDS }\end{array}$ \\
\hline $\begin{array}{l}\text { Avihingsanon, } \\
2010 \text { [15] }\end{array}$ & Thailand & $\begin{array}{l}2 \text { arms; } \\
\text { ITT }\end{array}$ & 16 & $\begin{array}{l}34^{\mathrm{a}} \\
\text { (range: 30-39) }\end{array}$ & $12 \%$ & $\begin{array}{l}\text { TDF + FTC } \\
(600 \mathrm{mg}+ \\
300 \mathrm{mg} / \mathrm{D}) \\
\text { vs FTC } \\
(300 \mathrm{mg} / \mathrm{D})\end{array}$ & $12,24,48$ & $\begin{array}{l}\text { Versant HBV DNA } \\
\text { 3.0 bDNA assay } \\
\text { (Bayer } \\
\text { HealthCare, NY); } \\
\text { COBAS TaqMan } \\
\text { HBV Test (Roche } \\
\text { Diagnostics NJ). }\end{array}$ & Hetero (75\%) & $\begin{array}{l}\text { EFV ( } 600 \text { mg } \\
\text { single dose/D) }\end{array}$ \\
\hline Gu, 2014 [28] & China & $\begin{array}{l}2 \text { arms; } \\
\text { ITT }\end{array}$ & 50 & 36 (SD:士9.5) & $88 \%$ & $\begin{array}{l}\text { TDF+ LMV } \\
\text { vs LMP }\end{array}$ & $12,48,96$ & $\begin{array}{l}\text { COBAS } \\
\text { Ampliprep/ } \\
\text { COBAS TaqMan }\end{array}$ & $\begin{array}{l}86 \% \text { hetro }+ \\
\text { homo: } 51.2 \% \\
\text { MSM }\end{array}$ & ART received \\
\hline $\begin{array}{l}\text { Wang, } \\
2016 \text { [29] }\end{array}$ & China & $\begin{array}{l}2 \text { arms; } \\
\text { ITा }\end{array}$ & 80 & $\begin{array}{l}29^{\mathrm{a}} \\
\text { (range: 24-36) }\end{array}$ & $0 \%$ & $\begin{array}{l}\text { TDF + LMV } \\
\text { vs LMV }\end{array}$ & 36 & $\begin{array}{l}\text { m2000 RT } \\
\text { System (Abbott } \\
\text { RT HBV Assay, } \\
\text { California), }\end{array}$ & - & $\begin{array}{l}\text { pregnant } \\
\text { women }\end{array}$ \\
\hline
\end{tabular}

$A R T$ antiretroviral therapy, $D$ day, exp. experienced, hetro hetrosexuial contacts, homo homosexual contacts, ITT intention-to-treat analysis, IVDU intravenous drug users, MSM men who have sex with men, RT RealTime, SD standard deviation, SVR suppression of viral loads, yr. year; ${ }^{a}$ medium; $\$$ median value (range or IRQ values are not provided) 
GRADE approach described elsewhere [17, 20, 23, 24]. We rated direct evidence from RCTs, using the standard GRADE approach on the five categories such as study limitations (risk of bias), precision, consistency of results, directness of evidence and publication bias. On these five categories, we judged the overall confidence in estimates of effect for virologic responses for each direct comparison as 'high,' 'moderate,' 'low' or 'very low' quality of evidence. For indirect comparison, we rated evidence from the most dominant first-order loop by first taking the lowest certainty of direct comparisons. We considered further rating down, if there were concerns with intransivity [24]. For NMA mixed estimates, we started with the higher quality of the two certainty ratings and rated down certainty for incoherence (degree of inconsistency between direct and indirect effect estimates) in the final quality rating $[23,24]$. We did not rate down intransivirty [11] in the current study as there was no important imbalance in the distribution of effect modifiers (e.g. age, gender, dosage) across seven studies. Pairwise meta-analysis was done with RevMan 5.3 (The Nordic Cochrane Centre, The Cochrane Collaboration), while network meta-analysis was with STATA 15.0 (StataCorp, TX).

\section{Results}

\section{Trials included}

Figure 1 shows a four-phase study selection process. The initial search yielded 1171 citations. After the title and abstract screening, 25 full-text papers were reviewed and a final of 7 studies $(n=329)$ were included in this review $[14,15,25-29]$. The largest comparison was LMV versus placebo $(n=122,32.4 \%)$, followed by LMV versus TDF plus LMV ( $n=116,31 \%)$. A summary of the 18 excluded studies $[2,6,7,30-44]$ is provided in Additional file 2: Table 1 presents the characteristics of the included studies. The number of participants ranged from 12 [25] to 122 [14]. Three RCTs were multi-country studies [14, 25, 27], two RCTs were from China $[28,29]$ and one RCT each was from Thailand [15] and the USA [26]. Six studies were two-arm RCTs [14, 15, 25, 26, 28, 29], and only one study was a three-arm RCT [27]. The distribution of studies and comparisons are presented in Additional file 3. The risk of bias was affected by inadequate information on the allocation concealment and the blinding status of the RCTs included (Additional file 4).

\section{Six-node analysis}

Figure 2 shows a network geometry of treatment success and provides eight direct $(n=329)$ and seven indirect comparisons for six treatment options. Six treatment options included were five antiviral drugs such as adefovir dipivoxil (ADV), FTC, LMV, TDF, TDF plus LMV and placebo. The contributing plot indicates the contribution of each direct comparison to indirect and network estimates (Fig 3). The weighted percentage contributions of each comparison were distributed fairly equally in the entire network of evidence. The global Wald test suggested the presence of consistency in the network $\left[\mathrm{Chi}^{2}(4)=3.63, p=0.46\right]$.

Pairwise analysis of the relative efficacy of antiviral for viral suppression in HBV/HIV was reported from eight pairwise comparisons. The result is very low certainty of evidence that there were no differences between the treatment regimens in virologic response and wide 95\%CIs, which spanned both benefit and harm (Fig 4).

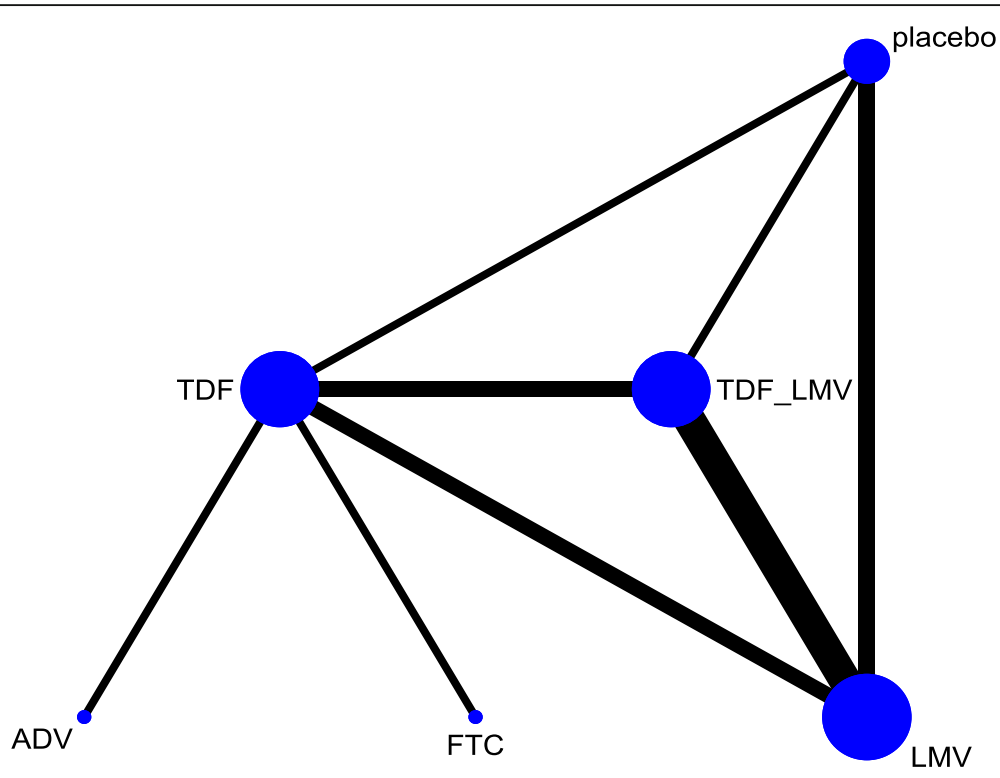

Fig. 2 Network map of different antiviral drugs for treating hepatitis B and HIV co-infected patients 


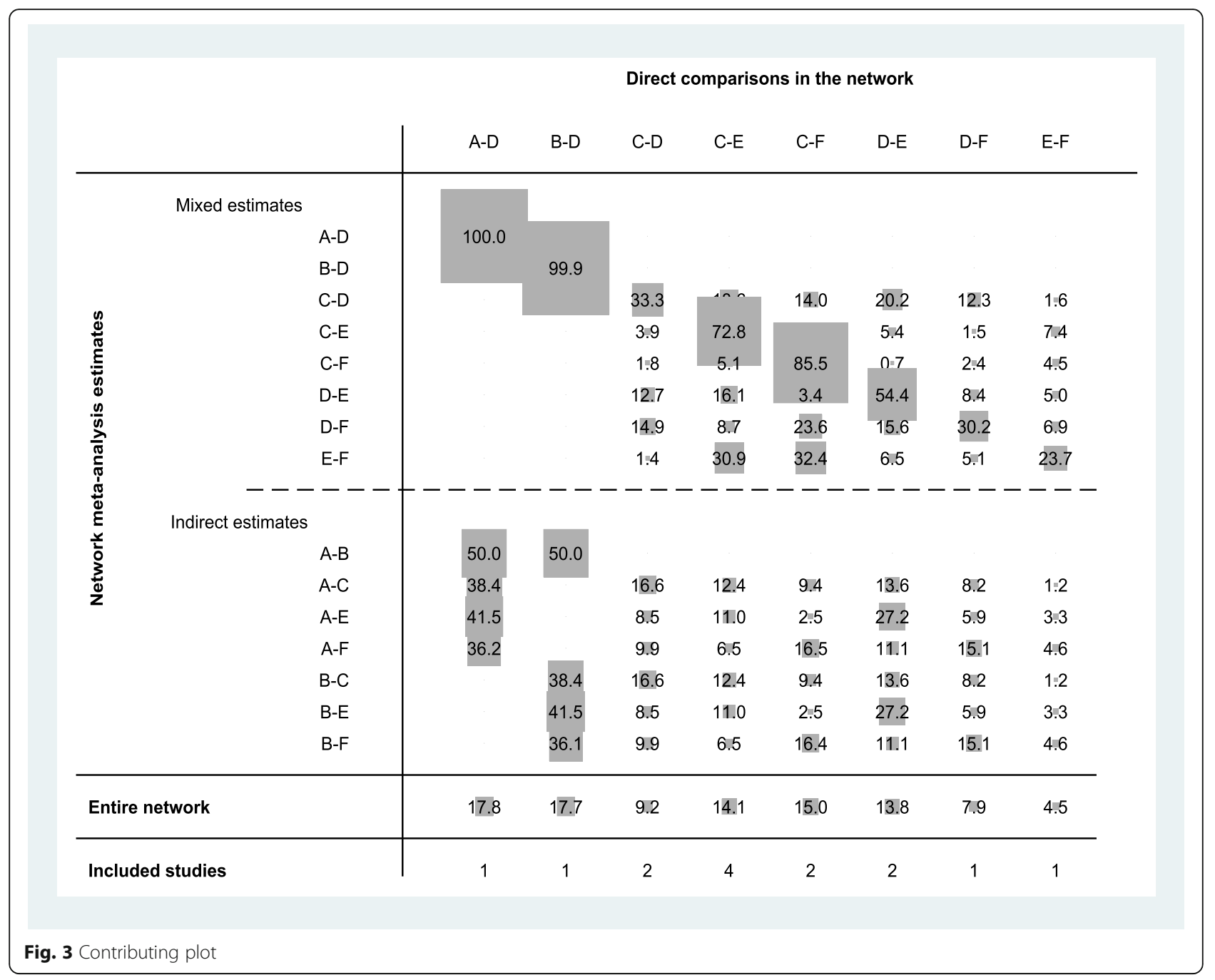

For instance, four studies compared LMV with TDF plus LMV. There was no difference between the two regimens in virologic response (LMV vs TDF plus LMV (OR 0.37, 95\%CI: 0.06-2.41; 218 fewer (121 more to 602 fewer) per 1000 patients, very low certainty). A single trial reported no difference between FTC and TDF in virologic response for the co-infected patients (FTC vs TDF (OR 0.07, 95\%CI: 0.00-1.14; 166 more (199 more to 310 fewer) per 1000 patients, very low certainty] (Table 2). The direct, indirect and network (mixed) comparisons for the six-node comparison after completing assessment for GRADE criteria are presented in Tables 2, 3 and Fig 5.

Treatment relative ranking in the network meta-analysis is presented in Additional file 5. FTC had the highest probability of being the best choice for treating patients co-infected with HBV/HIV, with the TDF plus LMV combination being the second best. The SUCRA and ranking results are under the circumstances of small number of the included studies and wide estimates ranging from benefit to harm. The evidence on which the SUCRA rankings are warranted was of very low quality and therefore untrustworthy [45]. We made overall evidence in view of the GRADE approach rather than the SUCRA rankings (Fig 5).

Overall, there was very low certainty evidence whether any antiviral regimens included in this study were better in virologic response for treatment of HBV/HIV co-infected patients since the certainty of the evidence was assessed as very low.

\section{Other outcomes}

Due to the small number of studies, other outcomes limited the summary estimates. Two studies had reported that HBV DNA was significantly decreased after treatment $[14,28]$. With regards to the adverse events/serious adverse events, three studies included in this review had reported hepatic flare or ALT flare after initiation of antiviral treatments. Due to variations in antiviral drugs administered and/or inconsistences in reporting, it was 


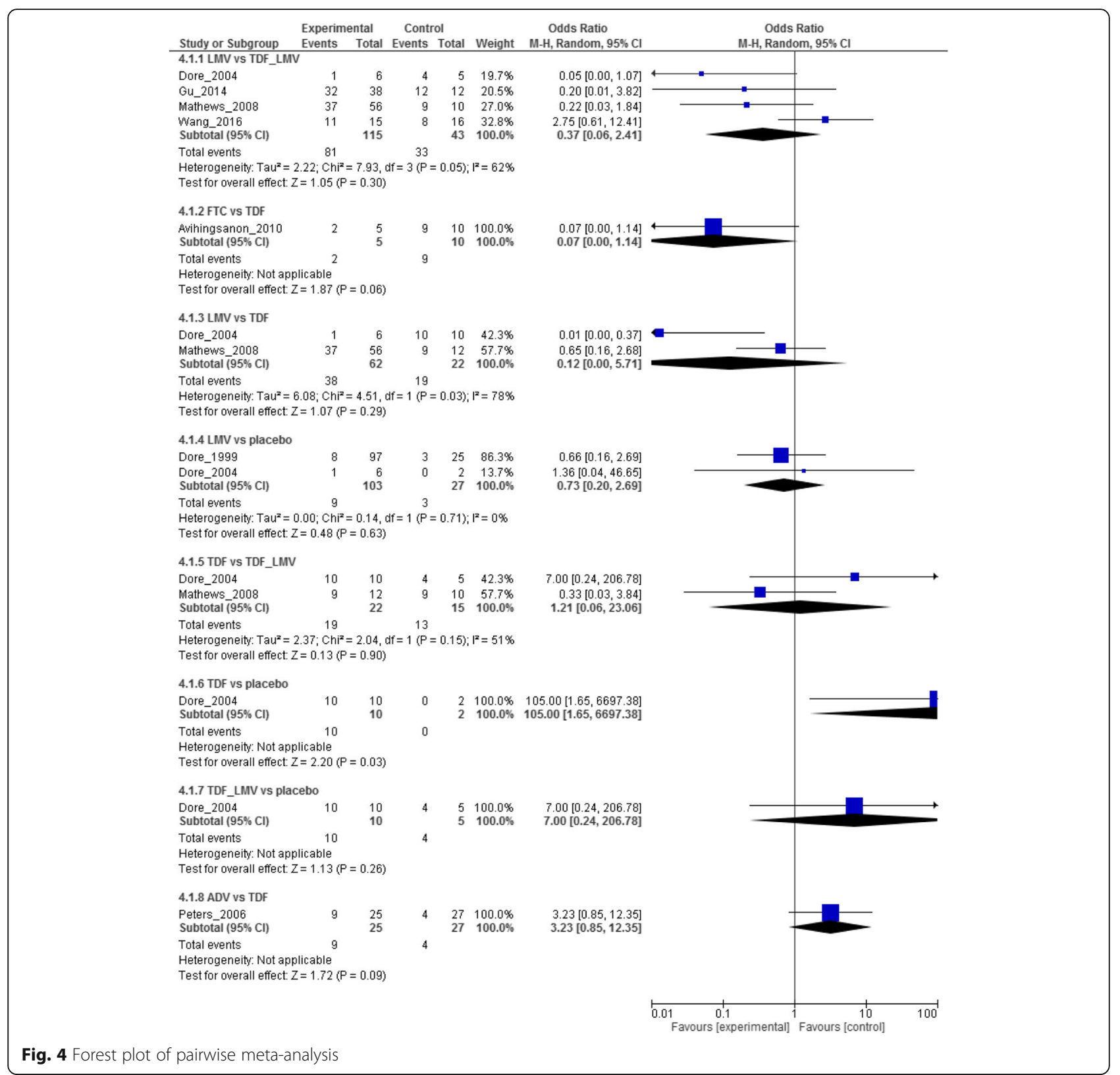

difficult to make the pooled analysis. The prevalence of hepatic flare after initiation of antiviral treatments was $54.5 \%(6 / 11)$ [25], while this was $21.2 \%(11 / 52)$ in one trial [26] and 19\% (3/16) in another trial [15]. These events were resolved, and none was associated with the development of hepatic decomposition $[15,25,26]$.

\section{Discussion}

\section{Summary of main results}

In this network meta-analysis, we have combined direct and indirect evidence on the relative efficacy of antiviral drugs interventions at the end of maximum 1 year treatment. The results of this NMA provide very low quality evidence that no regimen provided better rates of treatment success.

The use of virologic responses to represent suppression of HBV DNA after giving antiviral treatments served as surrogate outcomes in this review was clinically relevant. The main goal of the treatment of HBV infection was the sustained suppression of HBV replication because suppression is associated with a normalization of transaminase levels and improvement in histologic findings $[6,8]$.

There was only one study evaluating the efficacy of FTC and showed no difference in virologic response than the comparators. Also, any regimen in the current study was no different from the comparators and there 
Table 2 GRADE quality assessment of direct evidence of each pairwise treatment comparison for treatment success

\begin{tabular}{|c|c|c|c|c|c|c|c|c|c|}
\hline $\begin{array}{l}\text { Treatment } \\
\text { comparison }\end{array}$ & $\begin{array}{l}\text { Number of } \\
\text { head-to head } \\
\text { trials(n) }\end{array}$ & $\begin{array}{l}\text { Study } \\
\text { limitations' }\end{array}$ & Precision & Consistency & Directness & $\begin{array}{l}\text { Publication } \\
\text { bias }\end{array}$ & $\begin{array}{l}\text { Direct Estimate; } \\
\text { OR ( } 95 \% \mathrm{Cl})\end{array}$ & $\begin{array}{l}\text { Absolute effect per } \\
100 \text { treated }(95 \% \mathrm{Cl})\end{array}$ & $\begin{array}{l}\text { Overall } \\
\text { quality of } \\
\text { evidence }\end{array}$ \\
\hline $\begin{array}{l}\text { LMV vs TDF } \\
\text { plus LMV }\end{array}$ & $4(158)$ & serious $^{a}$ & very serious ${ }^{b}$ & $\begin{array}{l}\text { very serious } \\
\left(P^{2}: 62 \%\right)^{c}\end{array}$ & serious & likely to exist & $\begin{array}{l}0.37 \\
(0.06-2.41)\end{array}$ & $\begin{array}{l}218 \text { fewer } \\
\text { (from } 121 \text { more } \\
\text { to } 602 \text { fewer) }\end{array}$ & $\begin{array}{l}\text { very low } \\
\oplus \circ 0 \bigcirc\end{array}$ \\
\hline FTC vs TDF & $1(15)$ & serious $^{\mathrm{a}}$ & very serious ${ }^{a}$ & not serious & not serious & likely to exist & $\begin{array}{l}0.07 \\
(0.00-1.14)\end{array}$ & $\begin{array}{l}513 \text { fewer } \\
\text { (0 to } 11 \text { more) }\end{array}$ & $\begin{array}{l}\text { very low } \\
\oplus 00 \bigcirc\end{array}$ \\
\hline LMV vs TDF & $2(84)$ & serious $^{a}$ & very serious ${ }^{\mathrm{a}}$ & $\begin{array}{l}\text { very serious }{ }^{c} \\
\left(P^{2}: 78 \%\right)\end{array}$ & serious & likely to exist & $\begin{array}{l}0.12 \\
(0.00-5.71)\end{array}$ & $\begin{array}{l}27 \text { fewer ( } 87 \text { fewer } \\
\text { to } 141 \text { more) }\end{array}$ & $\begin{array}{l}\text { very low } \\
\oplus 00 \bigcirc\end{array}$ \\
\hline $\begin{array}{l}\text { LMV vs } \\
\text { placebo }\end{array}$ & $2(130)$ & serious $^{a}$ & very serious ${ }^{\mathrm{a}}$ & $\begin{array}{l}\text { not serious } \\
\left(P^{2}: 0 \%\right)\end{array}$ & serious & likely to exist & $\begin{array}{l}0.73 \\
(0.2-2.69)\end{array}$ & $\begin{array}{l}432 \text { fewer } \\
\text { (0 to } 109 \text { more) }\end{array}$ & $\begin{array}{l}\text { very low } \\
\oplus \circ 0 \bigcirc\end{array}$ \\
\hline $\begin{array}{l}\text { TDF vs TDF } \\
\text { plus LMV }\end{array}$ & $2(37)$ & serious $^{a}$ & very serious ${ }^{a}$ & $\begin{array}{l}\text { very serious }{ }^{c} \\
\left(P^{2}: 51 \%\right)\end{array}$ & serious & likely to exist & $\begin{array}{l}1.21(0.06- \\
23.06)\end{array}$ & $\begin{array}{l}21 \text { more ( } 127 \text { more } \\
\text { to } 586 \text { fewer) }\end{array}$ & $\begin{array}{l}\text { very low } \\
\oplus 00 \bigcirc\end{array}$ \\
\hline $\begin{array}{l}\text { TDF vs } \\
\text { placebo }\end{array}$ & $1(12)$ & serious $^{a}$ & very serious ${ }^{b}$ & not serious & not serious & likely to exist & $\begin{array}{l}105.00 \\
(1.65-6697.38)\end{array}$ & $\begin{array}{l}0 \text { fewer ( } 0 \text { fewer } \\
\text { to } 0 \text { fewer) }\end{array}$ & $\begin{array}{l}\text { very low } \\
\oplus 000\end{array}$ \\
\hline $\begin{array}{l}\text { TDF plus LMV } \\
\text { vs placebo }\end{array}$ & $1(15)$ & serious $^{a}$ & very serious ${ }^{b}$ & not serious & not serious & likely to exist & $\begin{array}{l}7.00 \\
(0.24-206.78)\end{array}$ & $\begin{array}{l}239 \text { more ( } 294 \\
\text { more to } 341 \text { fewer) }\end{array}$ & $\begin{array}{l}\text { very low } \\
\oplus \bigcirc 0 \bigcirc\end{array}$ \\
\hline ADV vs TDF & $1(52)$ & serious $^{a}$ & very serious ${ }^{\mathrm{b}}$ & not serious & not serious & likely to exist & $\begin{array}{l}3.23 \\
(0.85-12.35)\end{array}$ & $\begin{array}{l}212 \text { more (19 fewer } \\
\text { to } 534 \text { more) }\end{array}$ & $\begin{array}{l}\text { very low } \\
\oplus 000\end{array}$ \\
\hline
\end{tabular}

For domains "Study Limitations", "Precision", "Consistency", and "Directness": rated as not serious, serious, or very serious issues. For the domain "Publication bias": not likely or likely to exist. Reasons are provided when rating down. All direct comparisons begin with a "High" rating. "Rated down one level for risk of bias as study limitations; ${ }^{b}$ Rated down two levels for imprecision; ${ }^{c}$ Rated down two levels for substantial heterogeneity based on $I^{2}$ values; $C I$ Confidence interval, OR Odds ratio. ADV Adefovir, FTC Emtricitabine, LMV Lamivudine, TDF Tenofovir disoproxil fumarate, TDF plus LMV Combined Tenofovir disoproxil fumarate and Lamivudine

were wide CIs. In the GRADE approach, it was rated down two levels for imprecision. Overall, the evidence was very low quality. Hence, the present findings were limited in definitively resolving the question of optimal treatment choice. Studies have reported that treatment responses to TDF plus LMV combination therapy would be likely to be mediated by TDF alone as LMV may have no or minimal antiviral efficacy in the presence of LMV-resistant HBV mutants [46]. A study had reported that TDF monotherapy could maintain effective viral suppression over up to 288 weeks of continuous therapy without the selection of TDF resistance [47]. The fact that the LMV monotherapy was ranked higher than the TDF monotherapy as found in this review was an unexpected outcome and this was very low certainty of evidence. Studies have reported that 3TC (LMV) resistant HBV emerged in about 40 and $90 \%$ of patients after 2 and 4 years on $3 \mathrm{TC}$ respectively [48], while TDF had a high resistance barrier with no resistance identified to date after up to 6 years of monotherapy for chronic hepatitis B [49]. A systematic review had highlighted that entecavir and TDF were most effective in HBeAgpositive treatment-naive patients, while TDF was most effective in $\mathrm{HBeAg}$ negative treatment-naive patients in

Table 3 Network estimates of treatment success with 95\% confidence intervals and GRADE assessments

\begin{tabular}{|c|c|c|c|c|c|c|}
\hline $\begin{array}{l}\text { Treatment } \\
\text { comparison }\end{array}$ & $\begin{array}{l}\text { Direct estimate; OR } \\
(95 \% \mathrm{Cl})\end{array}$ & $\begin{array}{l}\text { quality of } \\
\text { evidence }\end{array}$ & $\begin{array}{l}\text { Indirect estimate; OR } \\
(95 \% \mathrm{Cl})\end{array}$ & $\begin{array}{l}\text { quality of } \\
\text { evidence }\end{array}$ & $\begin{array}{l}\text { Network estimate; OR } \\
(95 \% \mathrm{Cl})\end{array}$ & $\begin{array}{l}\text { quality of } \\
\text { evidence }\end{array}$ \\
\hline ADV FTC & Not available & Not available & $0.02(0.00-3.01)$ & Very low $\oplus \circ ০ \bigcirc$ & $0.02(0.00-3.01)$ & Very low $\oplus \circ \circ \bigcirc$ \\
\hline ADV vs LMV & Not available & Not available & $0.07(0.00-3.36)$ & Very low $\oplus \circ ০ ০$ & $0.07(0.00-3.36)$ & Very low $\oplus \circ \circ \bigcirc$ \\
\hline ADV vs TD & Not available & Not available & $0.31(0.02-6.28)$ & Very low $\oplus \circ ০ ০$ & $0.31(0.02-6.28)$ & $\begin{array}{l}\text { Very low } \\
\oplus \text { OOOS }\end{array}$ \\
\hline $\begin{array}{l}\text { ADV vs TDF } \\
\text { plus LMV }\end{array}$ & Not available & Not available & $0.18(0.00-9.2)$ & Very low $\oplus \circ ০ ০$ & $0.18(0.00-9.2)$ & Very low $\oplus$ O০০ \\
\hline ADV vs placebo & Not available & Not available & $0.05(0.00-4.71)$ & Very low $\oplus \circ ০ ০$ & $0.05(0.00-4.71)$ & Very low $\oplus \circ \circ \bigcirc$ \\
\hline FTC vs LMV & Not available & Not available & $3.01(0.03-287.25)$ & Very low $\oplus \circ ০ ০$ & $3.01(0.03-287.25)$ & Very low $\oplus \circ \circ \bigcirc$ \\
\hline $\begin{array}{l}\text { FTC vs TDF } \\
\text { plus LMV }\end{array}$ & Not available & Not available & $7.82(0.08-778.9)$ & Very low & $7.82(0.08-778.9)$ & Very low \\
\hline FTC vs placebo & Not available & Not available & $2.23(0.01-370.4)$ & Very low $\oplus \circ ০ ০$ & $2.23(0.01-370.4)$ & Very low $\oplus \circ ০ ০$ \\
\hline
\end{tabular}




\begin{tabular}{|c|c|c|c|c|c|}
\hline $\begin{array}{l}\text { ADV } \\
{[28.5]}\end{array}$ & & & $\begin{array}{l}3.23(0.85-12.35) \\
1 \text { study: } n=52 ;\end{array}$ & & \\
\hline $\begin{array}{l}\text { 0.02 (0.00-3.01); } \\
\text { } ९ \bigcirc \bigcirc\end{array}$ & $\begin{array}{l}\text { FTC } \\
{[87.5]}\end{array}$ & & $\begin{array}{l}0.07(0.00-1.14) \\
1 \text { study: } n=15\end{array}$ & & \\
\hline $\begin{array}{l}\text { 0.07 (0.00-3.36); } \\
\oplus \bigcirc \bigcirc \bigcirc\end{array}$ & $\begin{array}{l}\text { 3.01 (0.03-287.25); } \\
\text { } \bigcirc \bigcirc \bigcirc\end{array}$ & $\begin{array}{l}\text { LMV } \\
{[59.4]}\end{array}$ & $\begin{array}{l}0.12(0.00-5.71) \\
I^{2}: 78 \% ; \\
2 \text { studies: } \mathrm{n}=84 ;\end{array}$ & $\begin{array}{l}0.37(0.06-2.41) \\
I^{2}: 62 \% ; \\
4 \text { studies: } n=158 ;\end{array}$ & $\begin{array}{l}0.73(0.2-2.69) \\
I^{2}: 0 ; \\
2 \text { studies: } \mathrm{n}=130 ;\end{array}$ \\
\hline $\begin{array}{l}\text { 0.31 (0.02-6.28); } \\
\oplus \bigcirc \bigcirc \bigcirc\end{array}$ & $\begin{array}{l}\text { 13.49(0.29-625.8) } \\
\oplus \bigcirc \bigcirc \bigcirc\end{array}$ & $\begin{array}{l}\text { 4.48 (0.38-52.31); } \\
\oplus \bigcirc \bigcirc \bigcirc\end{array}$ & $\begin{array}{l}\text { TDF } \\
{[47.7]}\end{array}$ & $\begin{array}{l}1.21(0.06-23.06) \\
I^{2}: 51 \% ; \\
2 \text { studies: } \mathrm{n}=384 ;\end{array}$ & $\begin{array}{l}105(1.65-6697) \\
1 \text { study: } n=12 ;\end{array}$ \\
\hline $\begin{array}{l}\text { 0.18 (0.00-9.2); } \\
\oplus \bigcirc \bigcirc \bigcirc\end{array}$ & $\begin{array}{l}\text { 7.82 (0.08-778.96) } \\
\oplus \bigcirc \bigcirc \bigcirc\end{array}$ & $\begin{array}{l}2.6(0.44-15.39) \\
\oplus \bigcirc \bigcirc \bigcirc\end{array}$ & $\begin{array}{l}\text { 0.58 (0.05-7.34) } \\
\oplus \bigcirc \bigcirc \bigcirc\end{array}$ & $\begin{array}{l}\text { TDF plus LMV } \\
{[73.2]}\end{array}$ & $\begin{array}{l}7.0(0.24-206.8) \\
1 \text { study: } n=15\end{array}$ \\
\hline $\begin{array}{l}\text { 0.05 (0.00-4.71); } \\
\oplus \bigcirc \bigcirc \bigcirc\end{array}$ & $\begin{array}{l}2.23(0.01-370.4) ; \\
\oplus \bigcirc \bigcirc \bigcirc\end{array}$ & $\begin{array}{l}\text { 0.74(0.06-8.71) } \\
\oplus \bigcirc \bigcirc \bigcirc\end{array}$ & $\begin{array}{l}\text { 0.17(0.01-4.85) } \\
\oplus \bigcirc \bigcirc \bigcirc\end{array}$ & $\begin{array}{l}\text { 0.28(0.02-5.3) } \\
\oplus \bigcirc \bigcirc \bigcirc\end{array}$ & $\begin{array}{l}\text { Placebo } \\
{[3.7]}\end{array}$ \\
\hline
\end{tabular}

Fig. 5 Results of pairwise meta-analyses and network meta-analysis with consistency model for antiviral treatment

all surrogates outcomes at the end of first year of therapy [50].

In published reviews, TDF demonstrated the most effective viral treatment for patients with chronic HBV $[50,51]$. This was not observed in this study on patients with dual HBV/HIV infection. This implied that TDF is less potent for suppression of HIV DNA. A concern is that suppression of HBV DNA to undetectable levels was determined in the study population with continuing antiviral therapy. Hence, the stability of treatment response, after stopping therapy has not yet been investigated.

\section{Study limitations}

Due to a small number of studies included in this review for direct comparison, there was inadequate statistical power to detect significant differences among the drugs evaluated. Moreover, the currently recommended limit of serum HBV-DNA diagnostic assays is $20 \mathrm{IU} / \mathrm{ml}$ or $10 \mathrm{IU} / \mathrm{ml}$ (around $100 \mathrm{copies} / \mathrm{ml}$ or 50 copies/ml) on the scheduled follow-up regardless of their HBeAg status. The studies included in this analysis used different threshold for the definition of virological suppression. For instance, it was a serum HBV-DNA < 1000 copies/ $\mathrm{ml}$ in one study [25], while other studies used $<400$ cop$\mathrm{ies} / \mathrm{ml}$ [14] or $<200$ copies/ml [26]. Due to the use of higher cut-off for quantification of serum HBV-DNA diagnostic assays in the primary studies, the misclassification bias is a concern. An interpretation of the findings, therefore, needs a caution regarding such bias.

Studies in non-English language may have been missed. Telbivudine is licensed for HBV and HIV treatment, but none of the included studies assessed this antiviral drug. As our focus was on clinical effectiveness only, the cost-effectiveness of preferentially using a particular drug intervention was not done and should be examined in future studies. The highest prevalence was observed in sub-Saharan Africa and East Asia, where $5-10 \%$ of the adult population was chronically infected with $\operatorname{HBV}[52,53]$. But, none of the RCTs were from sub-Saharan Africa, indicating a geographical imbalance and an interpretation of this review was limited with regard to generalizability. Available data was sufficient to summarize only one surrogate clinical outcome. Currently, there is no agreement on the most appropriate surrogate markers of a long-term outcome or even of the validity of on-treatment measurements [49].

Nevertheless, the outcome used in this review was reasonable; studies have shown that for treatment with LMV, telbivudine, and ADV, subsequent resistance is low for those whose viral load is maintained at less than 1000 copies/m [54].

\section{Clinical implications}

The escalating HIV burden in some countries with a background prevalence of chronic HBV infection will contribute to an increasing number of people with HIV-1/HBV co-infection in the affected countries. Thus, an antiviral agent with dual efficacy against HIV-1/HBV in combination with at least one other antiretroviral agent could provide a cost-effective approach to manage these two chronic viral infections in resource-limited countries [14].

\section{Conclusion}

The findings suggest that there was insufficient evidence to provide the relative effectiveness of currently available antiviral drugs with dual activity in treating co-infection of HBV/HIV. Future well-designed, large clinical trials in this field to address other important outcomes from different geographical settings are recommended. 


\section{Additional files}
Additional file 1: Citations and Ovid MEDLINE. (DOC $44 \mathrm{~kb}$ )
Additional file 2: Excluded studies and reasons for exclusion. (DOC 38 kb)
Additional file 3: Distribution of studies and comparisons. (DOC $40 \mathrm{~kb}$ )
Additional file 4: Risk of bias assessment by the review authors. (DOC $33 \mathrm{~kb}$ )
Additional file 5: Treatment relative ranking. (DOC $31 \mathrm{~kb}$ )

\section{Abbreviations}

ADV: Adefovir; ART: Antiretroviral therapy; CENTRAL: Cochrane Central Register of Controlled Trials; Cl: Confidence interval; FTC: Emtricitabine; GRADE: Grading of Recommendations Assessment, Development, and Evaluation; HBsAg: Hepatitis B surface antigen; HBV: Hepatitis B virus; HCC: Hepatocellular carcinoma; HIV: Human immunodeficiency virus; LMV: Lamivudine; NMA: Network meta-analysis; OR: Odds ratio; PRISMANMA: PRISMA Extension Statement for Reporting of Systematic Reviews Incorporating Network Meta-analyses of Health Care Interventions: RCT: Randomized trials; SUCRA: Surface under the cumulative ranking curve; TDF: Tenofovir disoproxil fumarate

\section{Acknowledgements}

The authors thank the patients and researchers of the primary studies. We are grateful to the editors and reviewers for their comments and helpful inputs. We thank our institutions for allowing us to perform this study. We thank Professor Frederick Smales and Dr. Sompong Vongpunsawad for input in the revised manuscripts. YP obtained the Research Chair Grant (NSTDA).

\section{Funding}

This work was supported by funding from the International Medica University (IMU), Malaysia [ID 351-2016]. The contents are the sole responsibility of the study authors and do not necessarily reflect the views of IMU. The funding agencies had no role in the study design, data collection or analysis, manuscript writing, or the decision to submit for publication.

\section{Availability of data and materials}

The data supporting the findings can be found in the main paper and an additional file.

\section{Authors' contributions}

KST: conceptualized, participated in its design, interpreted the results and helped to draft the manuscript, YP: participated in its design, collected data interpreted the results and helped to draft the manuscript. CN: designed, collected data, carried out the statistical analysis, wrote the first draft and revised the manuscript together with YP and KST. All authors read and approved the final version for submission.

\section{Ethics approval and consent to participate}

The need for approval was waived as this study solely used published human data.

\section{Consent for publication}

Not applicable

\section{Competing interests}

The authors declare that they have no competing interests.

\section{Publisher's Note}

Springer Nature remains neutral with regard to jurisdictional claims in published maps and institutional affiliations.

\section{Author details}

'International Medical University, Kuala Lumpur, Malaysia. ${ }^{2}$ Division of Tropical Heath and Medicine, James Cook University, Townsville, QLD, Australia. ${ }^{3}$ Centre of Excellence in Clinical Virology, Faculty of Medicine, Chulalongkorn University, Bangkok, Thailand.
Received: 24 April 2018 Accepted: 5 November 2018

Published online: 14 November 2018

\section{References}

1. Hilleman MR. Comparative biology and pathogenesis of AIDS and hepatitis B viruses: related but different. AIDS Res Hum Retrovir. 1994;10:1409-19.

2. Thio C, Seaberg E, Skolasky R. HIV-1, hepatitis B virus, and risk of liver-related mortality in the multicenter AIDS cohort study (MACS). Lancet. 2002;360: 1921-6.

3. Konopnicki D, Mocroft A, de Wit S, Antunes F, Ledergerber B, Katlama C, et al. Hepatitis B and HIV: prevalence, AIDS progression, response to highly active antiretroviral therapy and increased mortality in the EuroSIDA cohort. AIDS. 2005;19:593-601.

4. Alter MJ. Epidemiology of viral hepatitis and HIV co-infection. J Hepatol. 2006:44(1 Suppl):S6-9.

5. Soriano V, Perelson AS, Zoulim F. Why are there different dynamics in the selection of drug resistance in HIV and hepatitis $B$ and $C$ viruses? J Antimicrob Chemother. 2008:62:1-4.

6. Thio CL. Hepatitis B and human immunodeficiency virus coinfection. Hepatology. 2009;49.

7. Aggarwal R, Ranjan P. Preventing and treating hepatitis B infection. BMJ. 2004:329(7474):1080-6.

8. Benhamou Y, et al. Safety and efficacy of adefovir dipivoxil in patients coinfected with HIV-1 and lamivudine-resistant hepatitis B virus:an open-label pilot study. Lancet. 2001;358:718-23.

9. AIDSinfo. Guidelines for the Use of Antiretroviral Agents in Adults and Adolescents Living with HIV. https://aidsinfo.nih.gov/guidelines/html/1/ adult-and-adolescent-arv-guidelines/25/hbv-hiv Accessed 23 May 2018.

10. Salanti G, Ades AE, loannidis JP. Graphical methods and numerical summaries for presenting results from multiple-treatment meta-analysis: an overview and tutorial. J Clin Epidemiol. 2011:64:163-71.

11. Salanti G. Indirect and mixed-treatment comparison, network, or multipletreatments meta-analysis: many names, many benefits, many concerns for the next generation evidence synthesis tool. Res Synth Methods. 2012;3:80-97.

12. Cornell JE. The PRISMA extension for network meta-analysis: bringing clarity and guidance to the reporting of systematic reviews incorporating network meta-analyses. Ann Intern Med. 2015;162:797-8.

13. Higgins JPT, Green S (editors). Cochrane Handbook for Systematic Reviews of Interventions Version 5.1.0 [updated March 2011]. The Cochrane Collaboration, 2011. www.cochrane-handbook.org. Accessed 9 Mar 2018.

14. Dore GJ, Cooper DA, Barrett C, Goh LE, Thakrar B, Atkins M, et al. Dual efficacy of lamivudine treatment in human immunodeficiency virus/hepatitis B viruscoinfected persons in a randomized, controlled study (CAESAR). The CAESAR Coordinating Committee. J Infect Dis. 1999:180:607-13.

15. Avihingsanon A, Lewin SR, Kerr S, Chang JJ, Piyawat K, Napisianant N, et al. Efficacy of tenofovir disoproxil fumarate/emtricitabine compared with emtricitabine alone in antiretroviral-naive HIV-HBV coinfection in Thailand. Antivir Ther. 2010;15:917-22.

16. Higgins JP, Altman DG, Gøtzsche PC, Juni P, Moher D, Oxman AD, et al. Cochrane Bias methods group; Cochrane Statistical Methods Group The Cochrane Collaboration's tool for assessing risk of bias in randomised trials. BMJ. 2011;343:d5928.

17. Guyatt GH, Oxman AD, Vist GE, Kunz R, Falck-Ytter $Y$, Alonso-Coello P, Schünemann $H J$, for the GRADE working group. GRADE: an emerging consensus on rating quality of evidence and strength of recommendations. BMJ. 2008;336:924-6

18. Guyatt GH, Oxman AD, Montori $V$, et al. GRADE quidelines: 5. Rating the quality of evidence--publication bias. J Clin Epidemiol. 2011;64:1277-82.

19. Shim S, Yoon B-H, Shin I-S, Bae J-M. Network meta-analysis: application and practice using Stata. Epidemiology and Health. 2017;39:e2017047.

20. Balshem $H$, Helfand M, Schunemann HJ, et al. GRADE quidelines: 3. Rating the quality of evidence. J Clin Epidemiol. 2011;64:401-6.

21. Chaimani A, Higgins JPT, Mavridis D, Spyridonos P, Salanti G. Graphical tools for network meta-analysis in STATA. PLoS One. 2013;8(10):e76654.

22. White IR, Barrett JK, Jackson D, Higgins JP. Consistency and inconsistency in network meta-analysis: model estimation using multivariate metaregression. Res Synth Methods. 2012;3:111-25.

23. Brignardello-Petersen R, Bonner A, Alexander PE, Siemieniuk RA, Furukawa TA, Rochwerg B, GRADE Working Group. Advances in the GRADE approach to rate the certainty in estimates from a network meta-analysis. J Clin Epidemiol. 2018;93:36-44 [Corrigendum to "Advances in the GRADE 
approach to rate the certainty in estimates from a network meta-analysis" [J Clin Epidemiol 2018;93:36-44].

24. Salanti G, Del Giovane C, Chaimani A, Caldwell DM, Higgins JP. Evaluating the quality of evidence from a network meta-analysis. PLoS One. 2014;9(7):e99682.

25. Dore GJ, Cooper DA, Pozniak AL, DeJesus E, Zhong L, Miller MD, et al. Efficacy of tenofovir disoproxil fumarate in antiretroviral therapy-naive and experienced patients coinfected with HIV-1 and hepatitis B virus. J Infect Dis. 2004;189:1185-92.

26. Peters MG, Andersen J, Lynch P, Liu T, Alston-Smith B, Brosgart CL, et al. Randomized controlled study of tenofovir and adefovir in chronic hepatitis B virus and HIV infection: ACTG A5127. Hepatology. 2006;44:1110-6.

27. Matthews GV, Avihingsanon A, Lewin SR, Amin J, Rerknimitr R, Petcharapirat $R$, et al. A randomized trial of combination hepatitis $B$ therapy in HIV/HBV coinfected antiretroviral naive individuals in Thailand. Hepatology. 2008;48: 1062-9.

28. Gu L, Han Y, Li Y, Zhu T, Song X, Huang Y, et al. Emergence of lamivudineresistant hbv during antiretroviral therapy including lamivudine for patients coinfected with HIV and HBV in China. PLoS One. 2015;10:e0134539.

29. Wang L, Wiener J, Bulterys M, Wei X, Chen L, Liu W, et al. Hepatitis B virus (HBV) load response to 2 antiviral regimens, tenofovir/lamivudine and lamivudine, in HIV/HBV-coinfected pregnant women in Guangxi, China: the Tenofovir in pregnancy (TiP) study. J Infect Dis. 2016;214:1695-9.

30. Hoffmann CJ, Charalambous S, Martin DJ, Innes C, Churchyard GJ, Chaisson $R E$, et al. Hepatitis $B$ virus infection and response to antiretroviral therapy (ART) in a south African ART program. Clin Infect Dis. 2008:47:1479-85.

31. Gutierrez S, Guillemi S, Jahnke N, Montessori V, Harrigan PR, et al. Tenofovirbased rescue therapy for advanced liver disease in 6 patients coinfected with HIV and hepatitis B virus and receiving lamivudine. Clin Infect Dis. 2008:46:e28-30.

32. Lacombe K, Gozlan J, Boyd A, Boelle PY, Bonnard P, Malean JM, et al. Comparison of the antiviral activity of adefovir and tenofovir on hepatitis $B$ virus in HIVHBV-coinfected patients. Antivir Ther. 2008:13:705-13.

33. Nuesch R, Ananworanich J, Srasuebkul P, Chetchotisakd P, Prasithsirikul W, et al. Interruptions of tenofovir/emtricitabine-based antiretroviral therapy in patients with HIV/hepatitis B virus co-infection. AIDS. 2008;22:152-4.

34. Alvarez-Uria G, Ratcliffe L, Vilar J. Long-term outcome of tenofovir disoproxi fumarate use against hepatitis B in an HIV-coinfected cohort. HIV Med. 2009; 10:269-73.

35. Idoko J, Meloni S, Muazu M, Nimzing L, Badung B, Hawkins C, et al. Impact of hepatitis $B$ virus infection on human immunodeficiency virus response to antiretroviral therapy in Nigeria. Clin Infect Dis. 2009;49:1268-73.

36. Engell CA, Pham VP, Holzman RS, Aberg JA. Virologic outcome of using tenofovir/emtricitabine to treat hepatitis $b$ in hiv-coinfected patients. ISRN Gastroenterol. 2011;405390.

37. Matthews GV, Manzini P, Hu Z, Khabo P, Maja P, Matchaba G, et al. Impact of lamivudine on HIV and hepatitis B virus-related outcomes in HIV/hepatitis $B$ virus individuals in a randomized clinical trial of antiretroviral therapy in southern Africa. AIDS. 2011;25:1727-35.

38. Nelson M, Amaya G, Clumeck N, da Cunha CA, Jayaweera D, Junod P, et al. Efficacy and safety of rilpivirine in treatment-naive, HIV-1-infected patients with hepatitis B virus/hepatitis C virus coinfection enrolled in the phase III randomized, double-blind ECHO and THRIVE trials. J Antimicrob Chemother. 2012;67:2020-8

39. Matthews GV, Ali RJ, Avihingsanon A, Amin J, Hammond R, Petcharapirat P, et al. Quantitative HBsAg and HBeAg predict hepatitis b seroconversion after initiation of HAARTt in HIV-HBV coinfected individuals. PLOS One. 2013; 8(4):e61297.

40. Kang M, Hollabaugh K, Pham V, Koletar SL, Wu K, Smurzynski M, et al. Virologic and serologic outcomes of mono versus dual HBV therapy and characterization of HIV/HBV coinfection in a US cohort. J Acquir Immune Defic Syndr. 2014;66:172-80.

41. Miailhes P, Maynard-Muet M, Lebossé F, Carrat F, Bouix C, Lascoux-Combe $C$, et al. Role of a 48-week pegylated interferon therapy in hepatitis $B$ e antigen positive HIV-co-infected patients on CART including tenofovir: EMVIPEG study. J Hepatol. 2014;61:761-9.

42. Yu S, Zhou Q, Zhao XM, Yuan M, Wang CT, Cheng XG, et al. Comparison of the antiviral effects of different nucleos(t)ide analogues in chinese patients with chronic hepatitis B: a head-to-head study. Saudi J Gastroenterol. 2014;20:350-5.

43. Lee T, Núnez M. Longer duration of HBV-active antiretroviral therapy is linked to favorable virological outcome in HIV-HBV co-infected patients. HIV Clin Trials. 2009;10:153-9.
44. Li Y, Xie J, Han Y, Wang H, Zhu T, Wang N, et al. Lamivudine monotherapybased cart is efficacious for HBV treatment in hiv/HBV coinfection when baseline HBV DNA <20,000 IU/mL. J Acquir Immune Defic Syndr. 2016;72: $39-45$.

45. Mbuagbaw L, Rochwerg B, Jaeschke R, Heels-Andsell D, Alhazzani W, Thabane $L$, et al. Approaches to interpreting and choosing the best treatments in network meta-analyses. Systematic Reviews. 2017;6:79.

46. Lim Y-S. Management of Antiviral Resistance in chronic hepatitis B. Gut and Liver. 2017;11:189-95.

47. Kitrinos KM, Corsa A, Liu Y, Flaherty J, Snow-Lampart A, Marcellin P, et al. No detectable resistance to tenofovir disoproxil fumarate after 6 years of therapy in patients with chronic hepatitis B. Hepatology. 2014;59:434-42.

48. AIDSinfo. Considerations for antiretroviral use in patients with coinfections. In: guidelines for the use of antiretroviral agents in HIV-1-infected adults and adolescents http://aidsinfo.nih.gov/guidelines Accessed 2 Apr 2018.

49. Heathcote J, Gane EJ, deMan RA, Sing C, Sievert W, Mauss S, et al. Two year tenofovir disoproxil fumarate (TDF) treatment and adefovir dipivoxil (ADV) switch data en HBeAg-positive patients with chronic hepatitis B (Study 103), preliminary analysis. Hepatology. 2008;48:376A.

50. Woo G, Tomlinson G, Nishikawa Y, Kowgier M, Sherman M, et al. Tenofovir and entecavir are the most effective antiviral agents for chronic hepatitis B: a systematic review and Bayesian meta-analyses. Gastroenterology. 2010; 139:1218-29.

51. Price H, Dunn D, Pillay D, Bani-Sadr F, de Vries-Sluijs T, Jain MK, et al. Suppression of HBV by tenofovir in HBV/HIV Coinfected patients: a systematic review and meta-analysis. PLoS One. 2010;8:e68152.

52. Schweitzer A, Horn J, Mikolajczyk RT, Krause G, Ott JJ. Estimations of worldwide prevalence of chronic hepatitis B virus infection: a systematic review of data published between 1965 and 2013. Lancet. 2015;386:1546-55.

53. World Health Organization. Hepatitis B. Geneva: WHO; 2017. http://www. who.int/mediacentre/factsheets/fs204/en/ Accessed 23 May 2018.

54. Kau A, Vermehren J, Sarrazin C. Treatment predictors of a sustained virologic response in hepatitis B and C. J Hepatol. 2008:49:634-51.

\section{Ready to submit your research? Choose BMC and benefit from:}

- fast, convenient online submission

- thorough peer review by experienced researchers in your field

- rapid publication on acceptance

- support for research data, including large and complex data types

- gold Open Access which fosters wider collaboration and increased citations

- maximum visibility for your research: over $100 \mathrm{M}$ website views per year

At $\mathrm{BMC}$, research is always in progress.

Learn more biomedcentral.com/submissions 